\title{
Observations on the Effect of a Ganglion Blocking Agent on Responses to Intravenous Glucose Infusion*
}

\author{
I. Burr, W. Hudson, D. Page, and H.P. TAFT \\ Diabetic and Metabolic Unit, Alfred Hospital Victoria, Australia
}

Received: November 3, 1969

Summary. The response of plasma glucose, insulin, growth hormone and cortisol to administration of small glucose loads by a previously described, primed infusion technique was determined in normal, diabetic and normal subjects who had been treated with pempidine. The normal subjects treated with pempidine had a glucose response similar to that observed in diabetics and an insulin response similar to that in 'late-onset' diabetics. Pempidine did not appear to affect growth hormone or cortisol response to glucose, but did inhibit the post-glucose fall in plasma insulin levels. Plasma cortisol levels tended to fall in response to this form of glucose administration. These findings are consistent with the concept of continuously acting, neural modification of glucose homeostasis in normal subjects, and the possibility that some of the early manifestations of diabetes result from a disturbance of this control.

Observations sur l'effet d'un agent de blocage ganglionnaire sur des réponses à une infusion intraveineuse de glucose

Résumé. Les réponses des taux sanguins du glucose, de l'insuline, de l'hormone de croissance et du cortisol ont été étudiées pendant l'administration de petites quantités de glucose par une technique antérieurement décrite d'infusion précédée d'une injection chez des sujets normaux, des diabétiques et des sujets normaux ayant été traités par la pempidine. Les sujets normaux prétraités par la pempidine présentaient une réponse glucidique comparable à celle des diabétiques et une réponse insulinique semblable à celle des diabétiques âgés. La pempidine ne semblait pas influencer la réponse de l'hormone de croissance et du cortisol après glucose, mais empêchait la baisse post-glucidique des taux plasmatiques de l'insuline. Avec cette méthode d'ad- ministration du glucose les taux du cortisol avaient tendance à diminuer. Les résultats sont en accord avec la conception d'une modification neurale permanente de l'homéostasie du glucose chez les sujets normaux et avee la possibilité qu'une part des manifestations précoces du diabète résultent d'un dérangement de ce contrôle.

Beobachtungen zur Wirkung eines Ganglien-Blockers auf Realtionen nach intravenöser Glucosezufuhr

Zusammenfassung. Das Verhalten von Blutzucker, Insulin, Wachstumshormon und Cortisol im Plasma nach Zufuhr kleiner Glucosemengen mittels einer früher beschriebenen Methode, bei der nach schneller Injektion eine Dauerinfusion von Glucose erfolgt, wurde bei Stoffwechselgesunden, Diabetikern und stoffwechselgesunden Probanden untersucht, die mit Pempidin behandelt worden waren. Die mit Pempidin vorbehandelten Kontrollpersonen zeigten einen Glucose-Anstieg, wie er bei Diabetikern zu beobachten ist, und eine Insulinausschüttung wie Altersdiabetiker. Pempidin schien das Verhalten von Wachstumshormon und Cortisol nach Glucose nicht zu beeinflussen, hemmte aber den Abfall der Plasma-Insulinspiegel nach Glucose-Gabe. - Die Plasma-Cortisolspiegel zeigten bei dieser Art der GlucoseVerabreichung eine fallende Tendenz. - Die Befunde stimmen überein mit der Annahme einer dauernd wirksamen nervalen Steuerung der Glucose-Homöostase bei Normalpersonen und mit der Möglichkeit, daß einige der Früherscheinungen des Diabetes auf einer Störung dieser Steuerungsmechanismen beruhen.

Key-words: Diabetes mellitus, regulation of blood glucose, insulin, central nervous system and blood glucose, autonomic nervous system and blood glucose, ganglion blocking agents, pempidine.

\section{Introduction}

The plot of blood glucose concentrations, achieved during intravenous glucose load-infusion studies, against time has revealed a much greater tendency to fluctuation in diabetic than in normal subjects [10]. This implies the existence of a continuously-acting mechanism in the normal individual which is responsible for reducing the magnitude of fluctuation under the conditions of this test.

In order to determine whether the autonomic nervous system played a role in this regulatory system, plasma glucose, cortisol, insulin and growth hormone responses to intravenous glucose load infusion were estimated in diabetic subjects and in normal subjects

* Submitted as part fulfillment of the requirements for Doctor of Medicine, Monash University, Melbourne, 1967. before and after administration of the ganglion blocking agent Pempidine (1:2:2:6:6 pentamethylpiperidine). Pempidine blocks both parasympathetic and sympathetic ganglia $[8,13,23,26,39,41]$ an effect mediated partly by inhibition of acetylcholine release $[1,13,41]$, possibly secondary to non-specific inhibition or impairment of a choline transport system [5]. This substance was chosen because of the rapidity of its action and excretion $[18,26]$. Some of this data has appeared previously in abstract form [9].

\section{Methods}

Patients were tested between 8 and 9 a.m. after a $12 \mathrm{~h}$ overnight fast. Insulin-dependent patients were studied at a time of minimal insulin activity, i.e. those on a single morning dose of NPH insulin or those using a short-acting insulin in the evening. Insulin was given 
on completion of the test. Patients controlled on sulphonylureas refrained from taking the agent for one (short acting) or two (long acting) days prior to the test. Diet-controlled patients were allowed a free diet for a minimum of three days prior to testing.

Blood was drawn from an antecubital vein via an indwelling scalp vein needle inserted one half hour before commencement of the tests. Needle patency was maintained by flushing with $\mathrm{N}$ saline, and error in sampling minimised by discarding $2 \mathrm{ml}$ prior to sample collection.

Glucose was administered intravenously as an initial priming dose of $126 \mathrm{mg} / \mathrm{kg}$ followed by a constant infusion of $250 \mathrm{mg} / \mathrm{min}$ (as $25 \%$ glucose) for $50 \mathrm{~min}$. Blood samples were withdrawn at zero time, at $5 \mathrm{~min}$ intervals through the test, and $20 \mathrm{~min}$ after cessation of the test for estimation of:

a) glucose in 23 diabetic subjects

34. untreated normal subjects

8 pempidine-treated subjects

b) insulin in 10 late-onset diabetics

17 untreated normal subjects

8 pempidine-treated normal subjects

c) growth hormone in 7 normal subjects 4 after pempidine administration, and at $0,20,50$ and $70 \mathrm{~min}$

d) plasma cortisol in 6 diabetic ( 3 early, 3 late-onset) 9 normal subjects

5 pempidine-treated normal subjects.

Pempidine was administered orally to 8 normal volunteer subjects, in doses varying from 15 to $17.5 \mathrm{mg}$ one hour prior to commencement of the glucose infusion test. This was done with the subject in a recumbent position in order to prevent possible onset of postural hypotension. Blood pressures and pulse rates were monitored at intervals of 5 minutes prior to, during, and following the test. Glucose concentration determinations were made by the SomogyiNelson procedure [31].

Plasma insulin was assayed by the method of Morgan and Lazarow [29] with modifications as suggested by Samols and Bilkes [37] and further changes as follows:

Human insulin was used as the standard. The time for the incubation of the second antibody reaction was 20 to $24 \mathrm{~h}$. The percentage bound was obtained by determining the ratio of count/min in the precipitate over counts $/ \mathrm{min}$ in $0.1 \mathrm{ml}{ }^{131} \mathrm{I}$-insulin.

On the 45 occasions in which plasma samples were assayed by the method described and by that of Berson and Yalow [3], the two methods showed close agreement.

Growth hormone was estimated by the method of Berson and Yalow [3]. Plasma cortisol was measured by a modification of the method of Mattingly [28] in which fluorimetric measurements were made at
5 rather than $13 \mathrm{~min}$ after addition of the fluorescence reagent [14].

\section{Results}

The maximum fall in blood pressure recorded in any subject after pempidine administration was $10 / 5 \mathrm{~mm} \mathrm{Hg}$, in another subject $5 / 5 \mathrm{~mm} \mathrm{Hg}$. In these subjects and in the remaining 6 , blood pressures were constant throughout the test and there was no alteration in pulse rate before or during the test. Marked

Table 1. Effect of pempidine on blood glucose fuctuation during constant glucose infusion*: Subject Sah failed to maintain blood glucose levels during the control infusion, blood glucose levels in this patient remained high and fuctuated grossly during infusion after pempidine administration

\begin{tabular}{lll}
\hline Subject & Control & Pempidine \\
\hline Lam & 5 & 17 \\
Mul & 4 & $\mathbf{1 9}$ \\
Far & 6 & $\mathbf{2 2}$ \\
Bu & 8 & $\mathbf{3 8}$ \\
Dar & 1 & $\mathbf{1 5}$ \\
Cor & 8 & $\mathbf{1 5}$ \\
Vds & 7 & $\mathbf{2 3}$ \\
Sah & falling & holding 31 \\
\hline & $\bar{x} \pm \mathrm{SD}=5.6 \pm$ & $\bar{x} \pm \mathrm{SD}=21.3 \pm$ \\
\hline
\end{tabular}

* Difference between maximum and minimum recorded glucose concentrations recorded during the latter 25 min of glucose infusion.

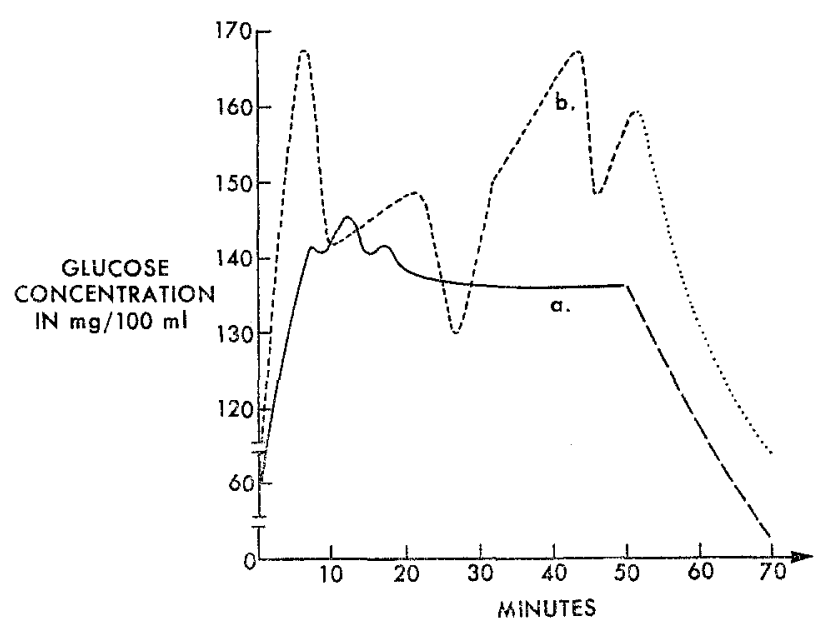

Fig. 1. Representative graphs, from subject Bu., showing blood glucose concentration during intravenous primed infusion a) control and b) post pempidine: solid line (a) and dashed line (b) connect values recorded at 5 minute intervals during glucose infusion, dashed line (a) and dotted line (b) indicate values after cessation of infusion

postural hypotension followed immediate resumption of the erect position on completion of the test in all subjects, usually associated with bradycardia; however there was no discomfort when the erect position was avoided for 4 to $6 \mathrm{~h}$ following the test. 
Table 2. Plasma insulin response to intravenous glucoseprimed infusion

\begin{tabular}{|c|c|c|c|c|c|c|}
\hline Subject & $\mathrm{Fa}$ & $\operatorname{Max}$ & $\operatorname{Max} 1$ & TM & Final & Final-Fa \\
\hline \multicolumn{7}{|l|}{ Normal: } \\
\hline Lam & 27 & 60 & 33 & 5 & 30 & +3 \\
\hline Cor & 26 & 35 & 9 & 5 & 26 & 0 \\
\hline Mul & 9 & 48 & 37 & 5 & 28 & +19 \\
\hline Gre & 29 & 45 & 16 & 5 & 26 & - \\
\hline Sah & 24 & 78 & 54 & 5 & 21 & -3 \\
\hline $\operatorname{Min} Y$ & 10 & 81 & 71 & 5 & - & - \\
\hline Joh & 25 & 83 & 58 & 5 & - & - \\
\hline Qui & 13 & 24 & 11 & 5 & 19 & +6 \\
\hline Dar & 10 & 25 & 15 & 5 & 1 & -9 \\
\hline $\mathbf{B u}$ & 1 & 7 & 6 & 5 & 1 & -0 \\
\hline Mab & 17 & 29 & 12 & 5 & - & - \\
\hline Far & 22 & 76 & 72 & 5 & 23 & +1 \\
\hline VdS & 2 & 30 & 28 & 5 & 2 & 0 \\
\hline Joh & 7 & - & - & $\cdots$ & 13 & +6 \\
\hline Buch & 12 & 一 & - & - & 19 & +7 \\
\hline \multicolumn{7}{|c|}{ Pregnant normal: } \\
\hline Whi J & 8 & 23 & 15 & 5 & 13 & +5 \\
\hline Boy & 10 & 25 & 15 & 5 & 5 & -5 \\
\hline \multicolumn{7}{|c|}{ Late-onset diabetics: } \\
\hline Whit & 32 & 66 & 44 & 50 & 32 & 0 \\
\hline \multirow[t]{2}{*}{ Cath } & 28 & 39 & 20 & 20 & 33 & 5 \\
\hline & 25 & 35 & 10 & 50 & 23 & 3 \\
\hline Merb & 1 & 44 & 43 & 10 & 16 & +15 \\
\hline Pick & 24 & 39 & 15 & 35 & 36 & +12 \\
\hline Han & 5 & 24 & 19 & 50 & 25 & +20 \\
\hline \multicolumn{7}{|c|}{ Pregnant late-onset diabetics: } \\
\hline Veev & 14 & 250 & 236 & 20 & 138 & +124 \\
\hline Ches & 7 & 28 & 21 & 45 & 27 & +20 \\
\hline Tsak & 8 & 32 & 24 & 15 & 23 & +15 \\
\hline Nap & 0 & 32 & 32 & 20 & 27 & +27 \\
\hline Dys & 26 & 68 & 42 & 45 & 54 & +28 \\
\hline
\end{tabular}

$\mathrm{Fa} \quad=$ Fasting plasma insulin in $\mu \mathrm{U} / \mathrm{ml}$

Max $=$ Maximum plasma insulin in $\mu \mathrm{U} / \mathrm{ml}$

Max $1=$ Maximum increment above fasting

TM = Time maximum level recorded in minutes after commencement of load-infusion test over this period. In 34 normal subjects the mean $\left(G_{\max }-G_{\min }\right)$ was $8 \mathrm{mg} / 100 \mathrm{ml}$, SD $4.3 \mathrm{mg} / 100 \mathrm{ml}$. In all 24 diabetic subjects, the $G_{m a x}-G_{m i n}$ was greater than $16 \mathrm{mg} / 100 \mathrm{ml}$, i.e. greater than $2 \mathrm{SD}$ above the normal mean. This difference is statistically significant, $34.8 \pm 18.1$ v. $8 \pm 4.1, p<0.01$ [10]. The values obtained for any individual, normal or diabetic, were reproducible with repeat testing. The mean $\left(G_{\max }-\right.$ $\left.G_{m i n}\right)$ in the 8 pempidine-treated patients was $21.3 \pm 8$ (SD), compared with $5.6 \pm 2.5$ (SD) in the same subjects without treatment (Table 1, Fig. 1). Subject Sah (Table 1) did not maintain blood glucose levels during the control load-infusion test; pempidine administration inhibited glucose disappearance in this patient, and was associated with gross fluctuations in glucose levels during the infusion. Statistical analysis of the remaining results revealed a significant difference between the control glucose responses and those follow. ing pempidine administration, $p<0.01$. There was no significant difference in this index between the pempidine-treated $(21.3 \pm 8)$ and the diabetic group, $(34.8 \pm 18)$. The results of tests performed on 4 of these patients, $3-6$ weeks after pempidine administration corresponded to initial control values.

Insulin responses (Table 2). In all normal subjects, the maximum plasma insulin level in response to intravenous glucose was recorded at $5 \mathrm{~min}$ and tended to fall to the fasting value on cessation of the infusion. The mean difference between the final ( 20 min after the infusion) and fasting insulin levels was $2 \mu \mathrm{U} / \mathrm{ml}$. None of the diabetic subjects achieved maximum plasma insulin levels in the 5 min sample - in all but 2 , maximum levels were obtained after $20 \mathrm{~min}$. The mean difference between the fasting and post-infusion plasma insulin concentration in the diabetics was $26 \mu \mathrm{U} / \mathrm{ml}$.

Table 3. Changes in the insulin response to the administration of glucose by the load infusion technique, induced by prior administration of pempidine

\begin{tabular}{|c|c|c|c|c|c|c|c|c|c|c|c|c|c|c|}
\hline \multirow[t]{2}{*}{ Subject } & \multirow[b]{2}{*}{$N$} & \multirow[b]{2}{*}{$P$} & \multicolumn{2}{|c|}{$\begin{array}{l}\text { Maximum } \\
\text { Increment }\end{array}$} & \multicolumn{2}{|c|}{$\begin{array}{l}\% \text { Maximum } \\
\text { Increment } \\
\text { above } F^{*}\end{array}$} & \multicolumn{2}{|l|}{$A^{*}$} & \multicolumn{2}{|c|}{$A^{*}$ as $\% F^{*}$} & \multicolumn{2}{|c|}{ Final level } & \multicolumn{2}{|c|}{ Final- $F *$} \\
\hline & & & $\bar{N}$ & $\vec{P}$ & $\bar{N}$ & $\bar{P}$ & $\bar{N}$ & $P$ & $\bar{N}$ & $\bar{P}$ & $\bar{N}$ & $P$ & $\bar{N}$ & $\bar{P}$ \\
\hline Lam. & 27 & 18 & 33 & 83 & 118 & 461 & 4 & 8 & 14.8 & 122 & 30 & 40 & 3 & 22 \\
\hline Cor & 26 & 29 & 9 & 17 & 34 & 58.6 & 3 & 8 & 11.1 & 27.1 & 26 & 42 & 0 & 13 \\
\hline Mul & 9 & 11 & 37 & 46 & 366 & 418 & 22 & 14 & 244 & 127 & 28 & 23 & 19 & 13 \\
\hline Sah & 24 & 12 & 54 & 43 & 225 & 341 & 23 & 21 & 100 & 175 & 21 & 23 & -3 & +11 \\
\hline Darg & 10 & 23 & 15 & 25 & 150 & 109 & 0 & 12 & 0 & 47 & 1 & 33 & -9 & +10 \\
\hline Farm & 22 & 9 & 54 & 49 & 250 & 545 & 11 & 9 & 50 & 100 & 23 & 18 & 1 & 9 \\
\hline $\mathrm{Bu}$ & 1 & 1 & 6 & 33 & 500 & 320 & 0 & 30 & 0 & 290 & 1 & 24 & 0 & 18 \\
\hline Vds & 2 & 6 & 28 & - & 1400 & - & 14 & 18 & 700 & - & 2 & 23 & 0 & 21 \\
\hline
\end{tabular}

$F^{*}=$ Fasting insulin level in $\mu \mathrm{U} / \mathrm{ml}$

$A=$ "Average" level above fasting (latter $25 \mathrm{~min}$ period) in $\mu \mathrm{U} / \mathrm{ml}$

$N=$ Normal

$P=$ Post pempidine

Glucose response. Fluctuation in blood glucose was estimated over the last $25 \mathrm{~min}$ of infusion by determining the difference between the maximum $\left(G_{m a x}\right)$ and minimum $\left(G_{m i n}\right)$ concentrations recorded
Comparison of the insulin responses in the normal and late-onset diabetic subjects failed to show any statistical difference in the maximum rise attained, the average level over the final 25 min of the infusion, 
or the increments above fasting. The most striking differences observed were a marked delay in achieving peak insulin levels in the diabetics and the failure to restore fasting insulin levels on cessation of the infusion in these subjects. This latter finding is significant $(t=2.932, p<0.005$ with $19 \mathrm{~d} . \mathrm{f})$.

Table 4. Plasma cortisol levels in response to glucoseprimed infusion ( $\mu \mathrm{g} / 100 \mathrm{ml}$ plasma)

\begin{tabular}{lccccc}
\hline Subject & Fasting & \multicolumn{3}{l}{$\begin{array}{l}\text { Minutes after commencement of } \\
\text { infusion }\end{array}$} \\
\cline { 3 - 6 } & & 5 & 20 & 50 & 70 \\
\hline Normals: & & & & & \\
JoH & 14.1 & - & - & 5.6 & 2.8 \\
Cor & 24.8 & - & - & 13.0 & 5.6 \\
MiY & 25.0 & - & - & 26.1 & - \\
Ta & 8.0 & - & 4.8 & 4.8 & 6.0 \\
Mul & 11.7 & - & - & 14.1 & 4.8 \\
Dar & 14.7 & - & - & 4.4 & 6.5 \\
Bu & 15.8 & - & - & 13.6 & 6.5 \\
Far & 21.7 & - & 14.4 & - & 17.3 \\
Dar & 39.7 & - & 21.0 & 23.2 & - \\
Late-onset diabetics: & & & & \\
Whi & 18.8 & - & 18.8 & 1 & - \\
Man & 52.0 & - & - & 21 & 28 \\
Pick & 24.0 & - & 20.3 & 14.2 & 16.7 \\
Early onset diabetics: & & & & \\
Bay & 13.2 & - & 9.6 & 14.4 & 15.6 \\
Ber & 36.2 & - & 30.1 & 26.5 & 22.0 \\
Lyg & 18.7 & - & 14.0 & 17.5 & 18.7 \\
\hline
\end{tabular}

Table 5. Effect of pempidine on plasma cortisol results ( $\mu \mathrm{g} / 100 \mathrm{ml}$ plasma)

\begin{tabular}{llllllr}
\hline Subject & $P / N^{*} F^{*}$ & \multicolumn{3}{c}{$\begin{array}{l}\text { Minutes after commencement } \\
\text { of glucose }\end{array}$} \\
\cline { 3 - 7 } & & & 5 & 20 & 50 & 70 \\
\hline Cor & N & 24.8 & - & - & 13.0 & 5.6 \\
& P & 14.2 & - & - & 11.9 & 11.9 \\
Mull & N & 11.7 & - & - & 14.1 & 4.8 \\
& P & 22.5 & - & - & 18.0 & 19.8 \\
Darg & N & 14.7 & - & - & 4.4 & 6.5 \\
Sahl & P & 35.0 & - & - & - & 18 \\
Far & P & 28.7 & 16.2 & - & 18.4 & 13.8 \\
& N & 21.7 & - & 14.4 & - & 17.3 \\
& P & 9.5 & - & 9.5 & 2.8 & 2.8 \\
\hline
\end{tabular}

* P Pempidine-treated

* $N$ Normal

* Fr Fasting

In all 8 subjects pretreated with pempidine, peak plasma insulin values were recorded at 5 min (Table 3 ); however, the differences between the final and fasting levels were greater following pempidine than under control conditions. The mean difference between final and fasting levels in the control studies was $1.4 \mu \mathrm{U} / \mathrm{ml}$ and following pempidine $14.5 \mu \mathrm{U} / \mathrm{ml}(p<0.01)$. Plasma insulin levels tended to be higher in response to glucose after pempidine administration. The maximum increment above fasting was increased in 6 of 7 subjects (not recorded in 1) and the average level in the last
$25 \mathrm{~min}$ expressed as a percentage of the fasting level, increased in 6 subjects. The tendency for insulin levels to return to fasting values on cessation of the glucose infusion in the control subjects was not observed in either the pempidine-treated or the diabetic groups. There was no significant difference in this respect between the diabetic and pempidine-treated groups.

Growth hormone response. Four subjects showed no change in fasting levels, which ranged from $<1$ to $2.4 \mathrm{~m} \mu \mathrm{g} / \mathrm{ml}$; two showed a fall of possible significance from 8 to $2.8 \mathrm{~m} \mu \mathrm{g} / \mathrm{ml}$ in one and 6 to $1.2 \mathrm{~m} \mu \mathrm{g} / \mathrm{ml}$ in the other; in one the values were unchanged but the sensitivity of the assay system precluded further comment in this case.

Pempidine had no significant effect on the growth hormone response to glucose infusion in the 4 subjects in which this was estimated.

Cortisol response (Table 4). In 8 of the 9 normal subjects, plasma cortisol levels fell during the glucose infusion - in 3 the values rose again within $20 \mathrm{~min}$ after cessation of the infusion.

In the 3 late-onset diabetics results were similar to those in the normal group, but in the 3 early-onset diabetics the reduction was less marked. This difference appeared significant $(p<0.025)$ despite the small numbers. Plasma cortisol concentrations fell in response to glucose infusion in pempidine-treated patients, and in two a subsequent rise was observed on cessation of the infusion. The results are similar to those observed in normal control subjects (Table 5).

\section{Discussion}

The significant increase in fluctuation of blood glucose levels observed in this study during glucose infusion induced by prior pempidine administration suggests that in normal individuals the Central Nervous System (CNS) exerts a 'dampening' effect which precludes marked fluctuation in blood glucose concentrations, and that this effect is mediated, at least in part, by the peripheral autonomic nervous system. The nature of this response is that which would be predicted if the nervous system dampening effect was achieved through control over the phasic relationship between the activity of factors which tend to raise and those which tend to lower blood glucose levels. Such control could be mediated indirectly through modification of the timing of hormonal responses to changes in glucose concentration and possibly through direct modifying control over hepatic and peripheral glucose metabolism.

The role of the CNS in the control of pituitary hormone release is well documented $[17,35]$, that this central control is responsive to changes in blood glucose concentrations has been demonstrated for Growth Hormone and ACTH release [36]. Further, peripheral autonomic and adrenaline responsiveness to hypoglycaemia has long been recognised [11, 15, 19, 38] and evidence in favour of central neural modi- 
fication of insulin secretion continues to accumulate $[7,20,21,25,32,33,34]$. That is, physiological mechanisms are available through which the CNS may exert glucose homeostatic control via modification of hormone release.

In these studies pempidine administration produced a persistent elevation in plasma insulin concentration, in contrast to the normal post-glucose infusion fall, i.e. it appeared to block an inhibitory influence on insulin secretion. This is consistent with the observation that adrenaline [24] and noradrenaline inhibit insulin release [33], an effect which is dependent on the integrity of pancreatic alpha-adrenergic receptors [32]. However, recorded changes in plasma growth hormone concentration provoked by glucose administration were minimal in this study, possibly due to the low glucose loads used; no alteration in this response was noted after pempidine administration. In contrast to normal, maturity-onset diabetic and pempidinetreated subjects, in subjects with early-onset diabetes cortisol levels failed to fall after glucose challenge. A similar disturbance of cortisol-releasing mechanisms has been reported in such patients by Lentle and Thomas [27]. It is unlikely that this type of response is secondary to long-term diabetes since it was not found in any of the late-onset diabetics, despite diabetes of long duration.

The temporal relationship of changes in the plasma glucose response to glucose after pempidine administration does not appear to be fully explained on the basis of recorded changes in plasma insulin, cortisol or growth hormone concentrations. This suggests the possibility of. a direct effect of the autonomic nervous system on glucose metabolism at the hepatic and peripheral tissuelevel. This possibility is supported by the prior observation that morphine-induced hyperglycaemia is abolished by complete sympathectomy but not by either lumbar sympathectomy or hepatic denervation [6]. Further, the post-hypoglycaemic increase in hepatic glucose output precedes any of the recognizable circulatory effects of adrenaline [2] and is inhibited by hexamethonium [4]. More recently, it has been demonstrated [40] that vagal stimulation increased the activity of hepatic glycogen synthetase (an effect modified by concurrent splanchnic stimulation) and one which occurs more rapidly than the similar effect of insulin. It is probable that acetylcholine is being constantly secreted by autonomic nerve endings [16]. Acetylcholine inhibits epinephrine-induced glycogenolysis [42] and the formation of cyclic $3^{\prime}-5$ ' AMP [30]. The rapid phase of secondary rise in hepatic glucose output may, therefore, result from either CNS-controlled inhibition of acetylcholine release or noradrenaline stimulation, or both, i.e. there are established mechanisms available for direct CNS modification of hepatic glucose release. This concept of direct neural modification of peripheral glucose metabolism may also apply to muscle. Constant nervous stimulation of muscle by tonic and postural reflexes is well recognized, and electrical stimulation of muscle results in a rise in intracellular free glucose [13]. Variations in this tonic effect could result in a modification of glucose handling by muscle tissue. Finally, data supporting the presence of glucose-responsive CNS control over lipolysis have been recently presented [11]. Thus, under physiological conditions glucose metabolism may be considered to be controlled at three different levels; the basal ability of tissues to metabolize glucose, the modification of this basal activity by hormonal and substrate factors; and finally a superimposed CNS influence providing an integrating or 'fine' control through direct modification of hepatic and peripheral tissue metabolism and modification of the timing and degree of glucose-responsive hormonal activity.

The possibility that disturbance of this CNS control mechanism may be an integral accompaniment of the diabetic state is suggested by the observation that the blood glucose and insulin responses to intravenous glucose administration in these studies were similar in diabetic and pempidine-treated subjects. Further, the observation of a similar response pattern in a high proportion of potential diabeties [10] suggests that this anomaly may appear early in the development of the clinical disorder.

Acknowledgement. The financial assistance of Burroughs Wellcome \& Co. (Australia) and the Alfred Hospital Research Committee; the technical assistance and advice of the Department of Biochemistry, Alfred Hospital, Victoria; Dr. John Owen, Director; and of Dr. Henry Burger, Associate Director, Medical Research Centre, Prince Henry's Hospital, Melbourne; the statistical help provided by Mr. J. A. Burr, Department of Mathematics, Melbourne and Swinbourne Technical Colleges, are all gratefully acknowledged.

\section{References}

1. Beani, L., Bianchi, C., Bieber, G., Ledda, F.: The effect of tubocurarine on acetylcholine release from motor nerve terminals. J. Physiol, 174, 172-183 (1964).

2. Bearn, A.G., Billing, B., Sherlock, S.: The effect of adrenaline and noradrenaline on hepatic blood flow and splanchnic carbohydrate metabolism in man. $J$. Physiol. 115, 430 - 441 (1951).

3. Berson, S.A., Yallow, R.S.: The Hormones. Ed. Pincus, G., Thimann, K.V., Astwood, E.B., vol. IV p. 557. New York: Academic Press 1964.

4. Billington, B.P., Paton, A., Reynolds, T.B., Sherlock, S.: Effect of hexamethonium bromide on circulatory and metabolic response to insulin hypoglycemia in men. J. Lab. clin. Med. 43, 880-887 (1954).

5. Birks, R., McIntosh, F.C.: Acetyleholine metabolism of a sympathetic ganglion. Canad. J. Biochem. 396 $787-827(1961)$

6. Bodo, R.C., CoTui, F.W., Benaglia, A.E.: Studies on mechanism of morphine hyperglycemia, role of sympathetic nervous system with special reference to sympathetic supply to liver. J. Pharmacol. exp. Ther. 62, 88-105 (1938).

7. Britton, S.W.: Studies on conditions of activity in endocrine glands, nervous control of insulin secretion. Amer. J. Physiol. 74, $291-308$ (1925). 
8. Buckley, J.P., Shanor, S.P., Gloss, J., Kinnard, W.J.: Evaluation of certain hypotensive agents. VI. Tetra methylpiperidine derivatives. J. Pharmac. Sci. 53, 24-28 (1964).

9. Burr, I.M.: Central Nervous System Control over Glucose Homeostasis. Proc. 59th Annual Meeting Amer. Soc. for Clin. Investigation 21-22 (1967).

10. - Hudson, W., Page, D., Taft, H.P.: The response to glucose intravenous infusion in normal and diabetic subjects. To be published Diabetologia.

11. Cannon, W.B., McTver, M.A., Bliss, S.W.: Studies on conditions of activity in endocrine glands, sympathetic and adrenal mechanism for mobilizing sugar in hypoglycemia. Amer. J. Physiol. 69, 46-50 (1924).

12. Conway, M.J., Goodner, C.J., Werrbach, J.H., Gale, C.C.: Studies of substrate regulation in fasting. II. Effect of infusion of glucose into the carotid artery upon fasting lipolysis in the baboon. J. clin. Invest. 48, 1349-1361 (1969).

13. Corne, S.J., Edge, N.D.: Pharmacological properties of pempidine (1:2:2:6:6 - pentamethylpiperidine), a new ganglion-blocking compound. Brit. J. Pharmacol 13, 339-342 (1958).

14. DeMoor, P.M., Steeno, O., Raskin, M., Hendriks, A.: Fluorimetric determination of free plasma hydrooxycorticosteroids in Man. Acta endocr. (Kbh.) 33, 297-300 (1960).

15. Dunér, H.: The effect of insulin hypoglycemia on the secretion of adrenaline and noradrenaline from the suprarenal of the cat. Acta physiol. scand. 32, 63-70 (1954).

16. Feldberg, W.: Synthesis of acetylcholine by tissue of central nervous system. J. Physiol. 103, 367-373 (1945).

17. Fortier, C.: Nervous control of adrenocorticotrophic hormone secretion, in The Pituitary Gland. Eds. Harris, G. W., and Donovan, B.T. Univ. of California Press Vol. 11 p. 195-234 (1966).

18. Harington, M., Kincaid-Smith, P., Milne, M.D.: Pharmacology and clinical use of pempidine in the treatment of hypertension. Lancet 1958 II, 6-9.

19. Holzbauer, M., Vogt, M. : The concentration of adrenaline in the peripheral blood during insulin hypoglycaemia. Brit. J. Pharmacol. 9, 249-252 (1954).

20. Kaneto, A., Miki, E., Kosaka, K., Okinaka, S., Nakao, K.: Effects of stimulation of the cingulate gyrus on insulin secretion. Endocrinology 77, 617-624 (1965).

21. Kasaka, K., Kaneto, A., Ide, J., Fukuchi, S., Kuzuya, T., Okinaka, S.: Effect of stimulation of the cerebellum on insulin secretion. Endocrinology 74, 361365 (1964)

22. Kipnis, D.M., Helmreich, E., Cori, C.F.: Studies of tissue permeability. IV. The distribution of glucose between plasma and muscle. J. biol. Chem. 234, $165-170(1958)$.

23. Kitchin, A., Lowther, C.P., Turner, R.W.D.: Pempidine. A ganglion-blocking drug for treating hypertension. Lancet $1961 \mathrm{I}, 143-145$.

24. Kris, A. O., Miller, R.E., Wherry, F.E., Mason., J.W.: Inhibition of insulin secretion by infused epinephrine in Rhesus monkeys. Endocrinology 78, 87-97 (1966).

25. LaBarre, J.: Role of central nervous system in control of pancreatic secretion; secretion of insulin during hyperglycemia. Amer. J. Physiol. 94, 13-16 (1930).

26. Lee, G.E., Wragg, W.R., Corne, S.J., Edge, N.D., Reading, H.W.: $1: 2: 2: 6: 6$-Pentamethylpiperidine: A new hypotensive drug. Nature 181, 1717-1719 (1958).

27. Lentle, B.C., Thomas, J.P.: Adrenal function and the complication of diabetes mellitus. Lancet 1964 II, $544-549$.

28. Mattingly, D.: A simple fluorimetric method for the estimation of free 11-hydroxycorticoids in human plasma. J. clin. Path. 15, 374-379 (1962).

29. Morgan, C.R., Lazarow, A.: Immunoassay of insulin using a two-antibody system. Proc. Soc. exp. Biol. 110, $29-32$ (1962).

30. Murad, F., Rall, T.W., Sutherland, E.W.: Formulation of adenosine-3, $5^{3}$-phosphate (3.5-AMP) by particulate preparation of ventricular muscle. Fed. Proc. 19, $296(1960)$.

31. Nelson, N.: Photometric adaption of Somogyi method for determination of glucose. J. biol. Chem. 153, $375-380$ (1944).

32. Porte, D., Williams, R.H.: Inhibition of insulin release by norepinephrine in man. Science 152, 12-48 $1250(1966)$

33. Porte, D.: A receptor mechanism for the inhibition of insulin release by epinephrine in man. J, clin. Invest. 46, 86-94 (1967).

34. Porter, R.W., Longmire, R.I., French, J.D.: Neurohumoral influence on gastric hydrochloric acid secretion. Fed. Proc. 12, 110 (1953).

35. Reichlin, S.: Regulation of somatotrophic hormone secretion, in the pituitary gland. Eds. Harris, G.W. and Donovan, B.T.: Univ. of California Press. Vol. 11 p. $270-298$ (1966).

36. Roth, J., Glick, S.M., Yalow, R.S., Berson, S.A.: Secretion of human growth hormone: Physiologic and experimental modification. Metabolism 12, $577-579(1963)$.

37. Samols, E., Bilkus, D.: A comparison of insulin immunoassays. Proc. Soc. exp. Biol. 115, $79-84$ (1964).

38. Setchell, B.P., Waites, G.M.H.: Adrenaline release during insulin hypoglycaemia in the sheep. J. Physiol. 164, 200-209 (1962).

39. Shanor, S.P., Kinnard, W.J., Buckley, J.P.: Cardiovascular activity of mecamylamine, pempidine, and several pempidine analogs. J. Pharmac. Sci. 54, $859-862(1965)$.

40. Shimazu, T.: Glycogen synthetase activity in liver: Regulation by the autonomic nerves. Science $\mathbf{1 5 6}$ $1256-1257$ (1967).

41. Spinks, A., Young, E.H.P.: Polyalkylpiperidines: A new series of ganglion-glocking agents. Nature 181, $1397-1398(1958)$.

42. Vincent, N., Ellis, S.: Inhibitory effect of acetylcholine on glycogenolysis in the isolated guinea pig heart. J. Pharmacol. exp. Ther. 139, 60-68 (1963).

Dr. Ian Burr

Université de Genève

Institut de Biochimie Clinique

Sentior de la Roseraie

CH-1211 Genève 4 